\title{
The Sustainability Narrative in Contemporary Architecture: Falling Short of Building a Sustainable Future
}

\author{
Igor Martek ${ }^{1}$, M. Reza Hosseini ${ }^{1, *(1)}$, Asheem Shrestha ${ }^{1}$, Edmundas Kazimieras Zavadskas 2 (ID) \\ and Stewart Seaton 1 \\ 1 School of Architecture and Built Environment, Deakin University, Geelong, Victoria 3220, Australia; \\ igor.martek@Deakin.edu.au (I.M.); asheem.shrestha@deakin.edu.au (A.S.); s.seaton@deakin.edu.au (S.S.) \\ 2 Institute of Sustainable Construction, Faculty of Civil Engineering, Vilnius Gediminas Technical University, \\ Sauletekio Ave. 11, Vilnius LT-10223, Lithuania; edmundas.zavadskas@vgtu.lt \\ * Correspondence: reza.hosseini@Deakin.edu.au
}

Received: 28 February 2018; Accepted: 25 March 2018; Published: 27 March 2018

\begin{abstract}
Sustainability has emerged, arguably, as the premiere mission of contemporary architecture. Green assessment tools abound, consultancy services flourish, buildings are marketed on the basis of sustainability performance, and government, media, and corporations seem preoccupied with assessing the quality of the built environment through a green lens. Yet for all the effort, and indeed for all the progress made, fundamental issues resistant to the structural change that is essential for genuine sustainability remain. This paper reviews the state of play of sustainability across the urban landscape. It considers the road travelled so far, and points out some of the major challenges that lie ahead.
\end{abstract}

Keywords: sustainability; green buildings; green development; green environment; rating tools; low carbon living; livable cities; sustainable cities; sustainability assessment tools

\section{Introduction}

Who would dare suggest that sustainability is anything but a good thing? With this simple test, it should be clear that sustainability is an ideology [1]. Nobody can deny its worth. However, in order to complete the test fairly, we need to ask "What does sustainability really mean?" The devil is in the details.

This study provides a broad overview of the sustainability narrative. It begins by answering the question of what sustainability means, noting that it is a trade-off between three competing ambitions: environmental protection, economic growth, and fairness for people [2]. It charts the historic development of sustainability consciousness in society. The rise of human civilisation has long been seen as synonymous with the conquest of nature and of overcoming natural barriers. Our confidence in controlling nature underlies both our belief that we are generating incalculable damage, and that we can and should do something about it [3].

Against this backdrop, the study goes on to chart the mission of architecture over the ages. Mostly, it was the preserve of tradition, encoding ritual, ceremony and value systems in built form. However, with the advent of industrialisation and the rise of the Modern Movement, architecture relinquished the past in favour of the future. The aims of 20th century architecture-in their various manifestations-was to generate utopias that embraced technology. The greatest legacy to arise out this was the "industrial city" - a concept that is still alive today, a century after its conception, and is largely indistinguishable from its manifestation as when first introduced. Here, utopia is a world full 
of factories, power plants, and railroads. The industrial city, then and now, seeks economic growth above all else [2,4].

Green sustainability rating tools arise out of the collision of these two agendas: continued economic growth, and redressing the environmental harm that such growth causes [5]. However, where is the correct balance to be found? How much economic benefit should we sacrifice in order to slow environmental damage? What economic practices must go, and what environmental goals should we prioritise? The study goes on to plot the rise and development of rating tools, noting that there are some 600 in use [6], each touting a different balance of give-and-take to the question [7].

Indeed, the academic world's contribution to the debate is to offer yet more varieties of rating tools. Rating "rating tools" is the new game in sustainability research. Over time, we see rating tools expanding vertically over industries and horizontally across value chains; expanding holistically to encompass whole regions; and collapsing microscopically to explore parameters in ever more refined nuances. However, we also see some pushback. Research also shows that rating tools may be failing to measure what they claim [8-10], either because they are off-plan and unverified, or because they actually get it wrong. Sometimes, the embodied energy of the components used in sustainable buildings generate a larger "carbon footprint" than the energy they purportedly save.

In the end, sustainability is a forum of ideas. It is a place where contesting interests struggle over what matters $[1,11,12]$. Rating tools are merely the physical artifacts of values generated by their proponents. What is most instructive is how more and more issues are being considered sustainability concerns. Sustainability is expanding to include so much that it risks being about nothing at all. This paper closes by reviewing the uncertainty of that legacy.

\section{Defining Sustainability}

The etymology of the word "sustainability" originates from the Latin sustinerre in which the words sub - from below - and tenere- - held up — combine to generate the idea of something that supports, maintains, or endures. According to the Oxford English Dictionary, the adjective form entered English usage in 1965 as an economics term — sustainable growth—and transformed into a developmental term in a 1972 report simulating population growth projections, which was entitled The limits of growth [13]. Terms such as "sustainable development" and "sustainable lifestyle" are now so commonplace in everyday parlance that it is hard to imagine that as recently as the 1980s the concept remained virtually unknown. Bill McKibben wrote the first ever book on climate change, which was published in 1989 [14]. Seven years later, in 1996, writing in the New York Times, he felt compelled to lament that "sustainability" would never catch on and would never become part of our social consciousness [15]. Yet beginning this century, there has been an explosion of attention afforded to the topic of sustainability. Today, a Google search of the term will return over 100 million hits.

Notwithstanding the newness of the term, "sustainability" has evolved significantly in meaning. It initially referred to practices that curbed environmental damage, and in that capacity, was the preserve of government regulators. However, the curtailment of resource exploitation and pollution came with a cost, and a second iteration of sustainability emerged which prioritised economic efficiencies in resource management. Then, in 2009, Mazmanian and Kraft observed that sustainability principles had begun to permeate societal values at large, and were influencing decisions made by individuals on a mass, personal scale, including what people bought, how they managed waste, and generally how they lived their lives [16].

At the institutional level, modern understandings of sustainability generally begin with the Brundtland Commission definition: Sustainable development is the development that meets the needs of the present without compromising the needs of future generations [17]. It describes sustainability as comprising an intersection of three elements: the environment, the economy, and equity. The premise is that all three elements must be preserved, and that any one element cannot be promoted at the expense of the others; sustainability is achieved when these are balanced. Sometimes, a fourth " $\mathrm{e}$ ", education, is added, reflecting the importance of community buy-in. Others argue that the relationship between 
elements is hierarchical, with the environment paramount, and thus best depicted as concentric circles, as shown in Figure 1. There are also a great many other definitions and conceptualisations.

The important point here is that the fluidity of the term impacts its adoption, interpretation, and execution $[18,19]$. An extreme scientific modelling approach was proposed by Albert Bartlett, concluding that sustainable growth was an oxymoron, where: Modern agriculture is the use of land to convert petroleum into food [20]. At the other end of the spectrum, John Dryzek contends that sustainability can never be more than a platform for debate [21]. Superficially, while sustainability may be conveniently summarised as the parallel pursuit of the three objectives of the "triple bottom line"- economy, environment, and society—it is plainly evident that no specific point of arrival can be articulated. In this regard, sustainability aligns more with abstract ideals such as justice, democracy, and virtue. Ultimately, sustainability is a philosophical problem that is concerned more with the conditions under which we should be living, rather than with the apprehension of a specific set of quantifiable performance measures [22].

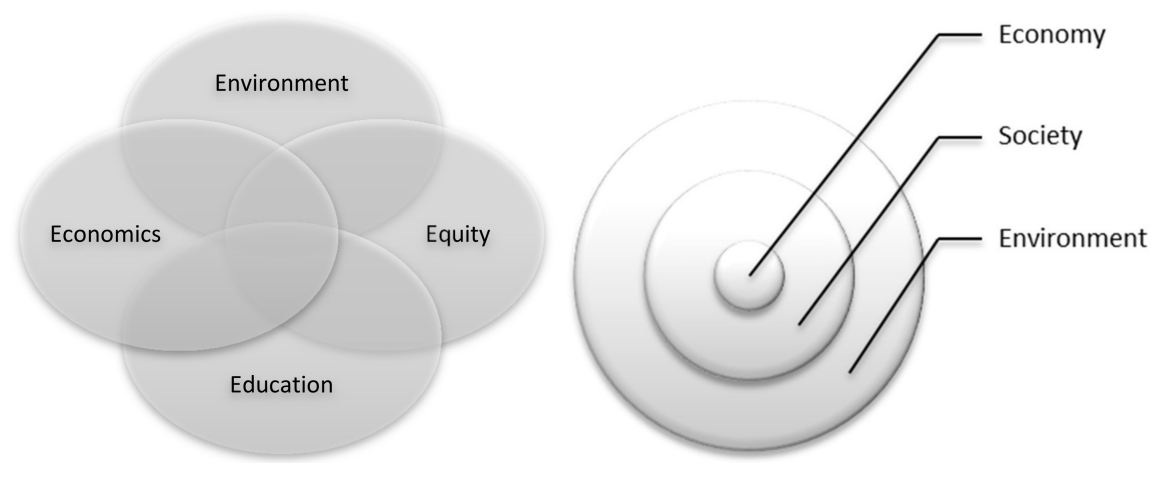

Figure 1. Depictions of the concept of sustainability [23].

\section{Attitudes to Nature across History}

In the far, distant past of pre-history, the world must have seemed to be a threatening and menacing place to our ancestors. Food sources were uncertain, natural phenomenon such as flood and drought hovered to unleash their fury, and predators, enemy tribes, and disease lurked at every turn. In the words of Thomas Hobbes, the political theorist, life was "solitary, poor, nasty, brutish, and short" [24]. Mankind's engagement with nature has shaped our attitude to it. For almost all of history, the challenge was to resist nature's onslaught, overcome the threat, and conquer it.

Early philosophical thought sought to reconcile mankind's place in nature. "Salvation" in primitive religion was communal. Deities were entreated to bless the crops and bring a bountiful harvest so that the whole tribe might survive to the next year. The conviction that developed was an anthropocentric view of the world in which the divine destiny of human beings was to rise over nature and dominate. For the Greeks, as exemplified by Socrates, the whole purpose of animals was to nourish humans. To the Roman Cicero, humans were on a higher plane than animals, which was evident in their ability to impose their will on raw creation, and in so doing improve it. With the emergence of cities and the accompanying transformation of the locus of salvation from group to the individual, mankind's ascendant position over nature consolidated. Perhaps one of the best-known ancient injunctions can be found in the Bible. God, speaking to Adam, instructs him: Be fruitful and multiply, and replenish the earth, and subdue it: and have dominion over the fish of the sea, and over the fowl of the air, and over every living thing that moveth upon the earth. (Genesis 1:28).

Through the Renaissance and Enlightenment periods, the capacity, and duty even, of mankind to perfect nature took on a secular flavor. Great influencers, such as Renè Descartes in his Discourse on Method, not only elevated the confidence of scientists and thinkers in the ability of human achievement, but the very act of introducing scientific methods to the exploration of the physical world, along with the reductionist approach to physical enquiry, diluted the mystery and enigma of nature into that 
of mere mechanisms. Viewing nature in terms of assembled components glossed the complexity of the holistic whole. Indeed, Newton's spectacular success in predicting the motion of planets and objects through physical laws transformed popular views of the universe as being just one big machine. The philosopher Herbert Spencer, writing in solidarity with Darwin's Origin of the Species, argued that survival of the fittest meant struggling against nature. Immanuel Kant went further, proclaiming that mankind alone has "understanding", giving him the right to rule over nature and relinquishing him of any moral responsibility with regards to his actions.

As distasteful as this amorality may seem to us today, when couched in the economic terminology driving current values, the message becomes familiar. Adam Smith asserted that individuals left to freely trade in consumer goods, and acting only out of their own self-interest, will ultimately generate the greatest enrichment for society as a whole; resources will be allocated efficiently. Through science, nature bends to human will, and human will arcs inevitably towards progress and the greater good. Even Marxism sees resources as nothing more than commodities, without recognising them as finite and depletable. For Marx, capital was the ultimate civilising force, which in the hands of the proletariat would see the renunciation of nature. In Pokrovsky's History of Russia, he proclaimed a criterion by which the Soviet struggle with the West would be measured: In the future, when science and technique have attained to a perfection which we are unable to visualise, nature will become soft wax in his [man's] hands which he will be able to cast into whatever form he chooses. Quoted in Ponting [25].

The lesson here is that while we may now accept that human activity has in fact damaged the environment to an extent that would have been unimaginable to the ancients, the belief remains that it is right and proper that we continue to intervene in nature in order to shape it to our will.

\section{Architectural Theory and Sustainability}

Serious architects, unlike construction managers, engineers, or perhaps any other professional, are prone to speak of their work in conceptual terms. Any respectable architecture program at university level will have a history and theory component. Styles from the ancient Classical, Romanesque, Norman, and Gothic; through Mannerism, the Baroque, Georgian, Victorian; to the Modernism, Bauhaus and International movements of the last century, all in their turn capture a "zeitgeist", or spirit of the age in which the aspirations of human civilisation are immortalised in the built form. The commonalities linking architectural forms speak to the perennial boundedness of the human condition: the need for shelter and for spaces to carry out both the mundane activities of everyday life, as well as the ceremonies and rituals that lift the soul. The differences between these forms speak to the evolutionary nature of human progress and the iterations in our efforts to lift ourselves into a better tomorrow. The comparison of architectural images, such as the two shown in Figure 2-Stonehenge, United Kingdom (UK), and the Marina Bay Sands Resort, Singapore-is an activity familiar to architects. What would they see? There is of course the remarkable technological differential that separates the 3800-year divide in construction dates. Yet, that divide is bridged in the realisation that the makers of both structures shared a driving ambition to impose their will on the landscape and bring their architectural vision into reality. The gesture of lintel and columns that are so evident in both structures would not be lost on Jungian psychologists, nor indeed on architects themselves.

However, a further question with regard to the images that is relevant to the discussion at hand would be to ask: which of the two structures represents a more sustainable solution? Answering is no mean feat, since in order to choose, a raft of parameters must be identified and evaluated. Essentially, to choose the ancient is to renounce current achievements, while choosing the modern is to qualify away current problems. This intractability must be met head on if the global sustainability project is to achieve genuine momentum.

The Gothic style lasted 500 years, from the 12th to 16th centuries, not to mention the period of revival it enjoyed in the 19th century. Its churches, too, took decades, if not a century to complete. These were communal projects; their artisans and architects were largely unknown. Soaring, vaulted 
ceilings reached for the heavens, and high stained-glass windows filtered light back down from the angels. Similar to much ancient architecture, the message in the light-as-air stonework spoke of a divine destiny for mankind on earth, the ultimate transcendence of the material world, and hope for the unspeakable beauty of the next. While we lived in this world, its stewardship was not a priority. We were only passing through; our reward lay in the next life.

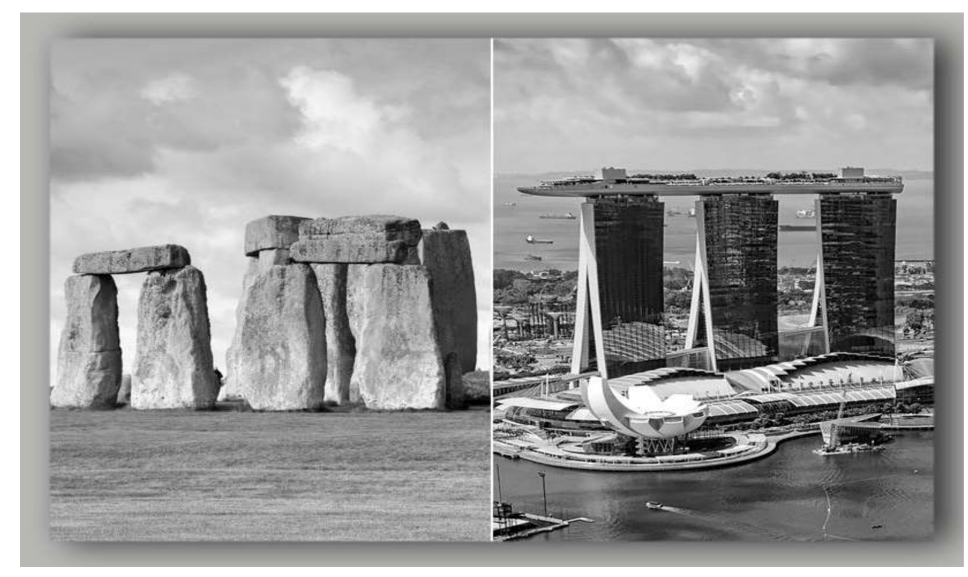

Figure 2. Stonehenge, United Kingdom (UK), (left) and the Marina Sands Beach Resort, Singapore (right) [26].

By contrast, the 20th century was forward-looking and materialistic. It was an epoch of rapid change, uncertainty, and anxiety, bringing in its wake a cascade of architectural movements. Functionalism took on what was being learned in the new sciences, and brought them into architecture. These were the biological, mechanical, gastronomic, and linguistic analogies [27]. Frank Lloyd Wright may be its best-known purveyor through his many organically designed masterpieces, while Louis Sullivan may have coined architecture's best known cliché: Form follows function [28]. By contrast, Revivalism was a nostalgic paradigm, a strategy for retreating from an uncertain and tumultuous present while looking for the imagined past idyllic. These were the Roman, Greek, Renaissance, above-mentioned Gothic, and other revivals, as well as experiments in polychromy and eclecticism. Other approaches attempted in their own various ways to reconcile the old and the new. Rationalism sought to synthesise past traditions into a machine age. Expressionism adopted new materials and technical innovations, but aimed at socialist and utopian, if not utterly fantastic ideals.

Historians will assess these movements and their contributions in any manner of ways, and have done so [29]. Ultimately, for all their perceived impact, they were relatively short-lived. The rationalisations that propelled them into existence all too quickly dried up or were superseded. The seminal works of these movements can be summarised in the key projects of their respective champions. However, individual architectural heroes aside, the tradition that has left the heaviest imprint on the built environment in terms of sustainability, and whose impact lingers despite the demise of the name under which it flourished, is undoubtedly the Modern Movement. An appreciation of this contention begins with a sober assessment of the degrading impact of the world population on the environment. Just how extreme population growth has been over the last few generations is made plain when considering Figure 3. For almost all of history, the total number of humans on the entire planet may have hovered at not much more than a few million. With the abandonment of hunting and gathering, and the adoption of settled agriculture, populations began to edge upwards. At $1000 \mathrm{BC}$, it may have jumped to 50 million, reaching one billion in the 1800s. By 1960, it was three billion, and today it is eight billion. Currently, 100 million people are added to the planet every year, which was the entire world population of ancient times. The sudden, recent, and exponential growth in population would not have been possible without the associated magnitudinal leap in industrialisation. While this 
link is well established, it is less appreciated that industrialisation itself was energised and spurred forward by the Modern Movement.

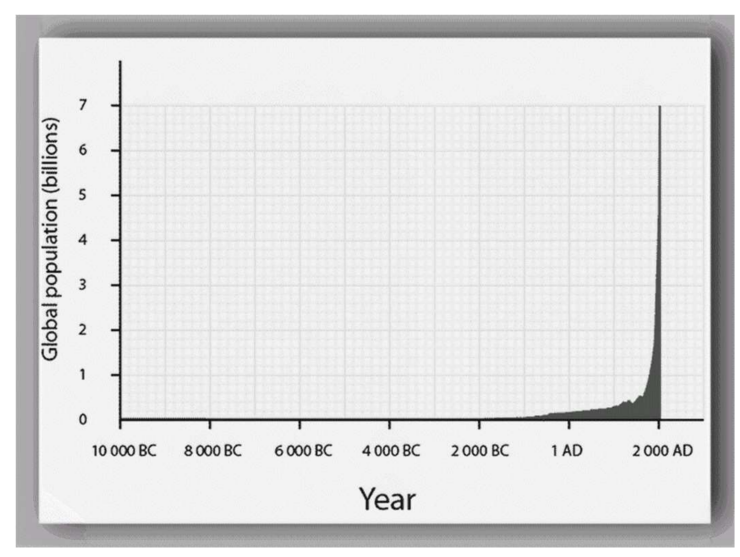

Figure 3. World population-10,000 BC to the present [30].

If the Modern Movement stood for anything, it stood for the belief that science and engineering, through the power of the human intellect, could solve any problem. An early advocate of the Modern Movement was Tony Garnier. He is known, firstly, for using concrete inside and outside buildings, and for doing so without concealing its inherent raw character; without ornamentation or reference to previous styles. He wrote: Ancient architecture is an error. Truth alone is beautiful. In architecture, truth is the result of calculations made to satisfy known necessities with known materials [31]. This again is the familiar cry of the primacy of human intellect and its ascendancy over nature. His great work, secondly, was in formulating the concept of the "industrial city". For all the subsequent criticisms that have been levelled against it, here, for the first time, was a manifesto on urban life that may be more familiar today than when it was conceptualised back in 1901. It was planned around the needs of factories and the workers that would fuel an economy dependent on productive output. An infrastructure grid of railways, roads, and communications networks ensured logistical efficiency. Surrounding dams and power stations provided the energy needed to keep the city alive. Here, for the first time, was a vision of the future that arguably has not dated. It is not only recognisable in today's cities, it also espouses values that even now permeate policy-making and social discourse, as shown in Figure 4. Critically, it is also dependent on the premise of an infinite, open system, where nature retains the capacity to supply an endless stream of input resources, while being able to absorb an endless waste output. The most significant environmental threat over the last 100 years is not so much how we build cities, but rather that we continue to build in much the same way, despite now knowing their limitations with regard to resource depletion and waste production.

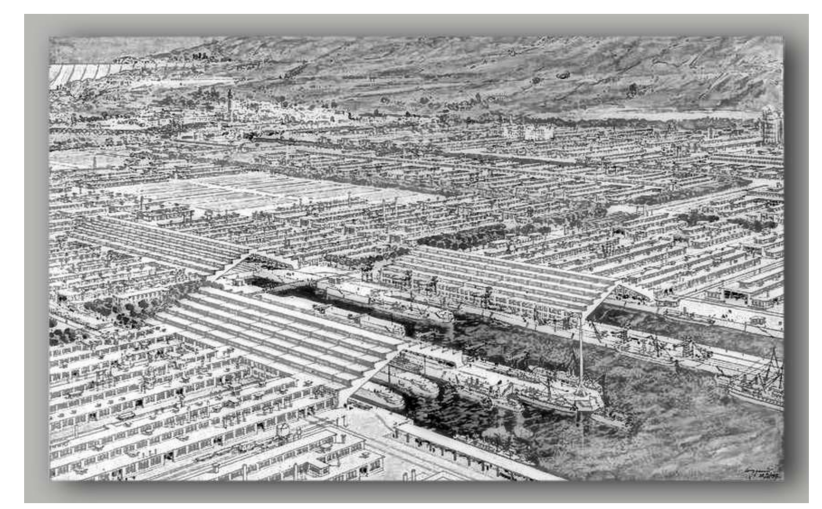

Figure 4. Tony Garnier's industrial city, 1901—wholly recognisable in the cities of today [32]. 


\section{Green Buildings and the Rise of Rating Tools}

Against this backdrop of rising concern regarding the impact of humans on the planet, building construction looms large as generating the greatest environmental damage [33]. Buildings consume one-third of all resources [34]. This breaks down as one-sixth of all freshwater usage, one-quarter of world wood harvests, and four-tenths of all other raw materials [35]. Moreover, close to $50 \%$ of all global energy usage and green-house gas emissions arise from building operations, with a further $10 \%$ of energy consumed in the manufacturing of building materials [36]. On top of all this, $40 \%$ of all waste produced worldwide is generated in the initial construction and later demolition of buildings [37,38].

The industrialisation process of the 19th and 20th century saw buildings move from being evaluated as communal assets in cultural terms, to private assets that primarily serve an economic function. Indeed, the evolution of building performance measures has a long history, shifting only in recent times from concerns of financial return and occupant health and safety, to accommodate environmental performance [39]. Nevertheless, while sustainability, greening, energy efficiency, and ecolabelling are now arguably the emergent priority of building and planning regulators, sustainability performance measures remain embedded in traditional assessment paradigms. Building codes and regulations, at least in the West, emerged as a result of the Great Fire of London in 1666, setting standards in construction that enhanced fire resistance. Later, these codes centered on structural design to ensure minimum standards of load-bearing capacity for anticipated dead and live loads. Health and safety were also incorporated, looking to ensure the well-being of occupants. Then, in the 1970s, the world was hit with the oil crisis. As a result, regulations were expanded to encompass considerations of energy efficiency $[8,40]$. When public interest was aroused in climate change in the 1990s, these codes were again extended. In Australia, energy efficiency was introduced into the residential building code in 2005, and then into the commercial building code in 2006. At first, this was limited to new buildings, but it was then brought across to include the refurbishment of existing structures [41].

What is important to understand here is that compliance with all of the relevant codes is a prerequisite to obtaining a building permit. That is, compliance is assessed prior to the building actually being built—it is assessed off the plan. Following this precedent, sustainability assessment, too, is done in this way-off the plan. The difficulty is that while the engineering design of a component is reliably predictive of the engineering components' performance, sustainability design is not [9]. For one thing, there is the problem of measurement. It is relatively easy to comprehend and observe structural failure. However, sustainability performance unfolds as a matter of degrees, and is not objectively quantifiable. Moreover, even more fundamentally, there is the problem of what it is that is actually being measured. There is agreement on what constitutes structural failure; there is far more controversy over what sustainable performance entails [6].

\section{Green Buildings and the Rise of Rating Tools}

Given the ingredients of a recent but rocketing concern over the environmental impact of the built environment, combined with a regulatory legacy steeped in off-plan compliance assessment and a culture of outsourcing assessment to commercial bodies vying in an open market, we have fostered the emergence of the competitive green-rating assessment regimes that we see today. Just as with any fast-growing market for a new high-demand product, green building rating tools have exploded onto the scene, with a plethora of providers offering all sorts of rating tool variations. At last count, there were over 600 such sustainability rating tools competing in the market [42]. Similar to any emerging market, the market for green rating tools is characterised by early entrants that have captured market share, followed by niche entrants that have tweaked initial offerings to serve specialist sectors or adapt to different regional conditions. The Building Research Establishment Assessment Method (BREEAM) dominates Europe, the Leadership in Energy and Environmental Design (LEED) is preeminent in America, the Comprehensive Assessment System for Built Environment Efficiency 
(CASBEE) is centered on Asia, and Green Star is the main provider in Australasia. A schematic of their evolutionary development is shown in Figure 5.

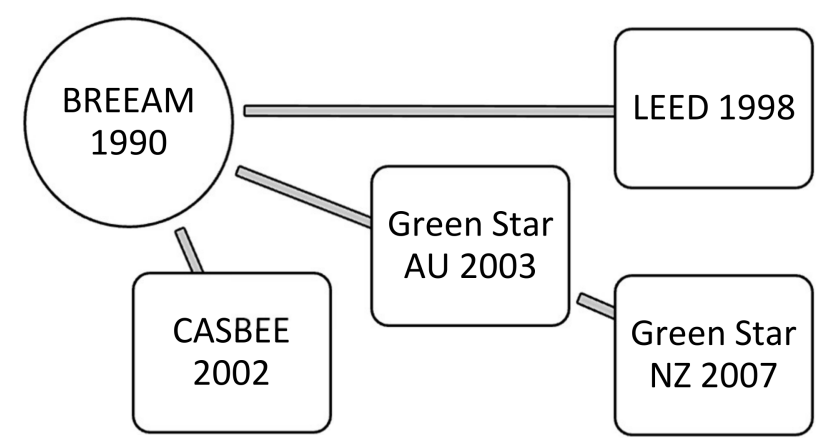

Figure 5. The product development pathway of the major global green rating tools [43]. BREEAM: Building Research Establishment Assessment Method; CASBEE: Comprehensive Assessment System for Built Environment Efficiency; LEED: Leadership in Energy and Environmental Design.

The Building Research Establishment Assessment Method, or BREEAM, is regarded as the first green building rating system. It was developed by the UK Building Research Establishment in 1990, and was revised in 1993 to assess new offices. Later, it was expanded again to include existing offices, supermarkets, and light industrial buildings. Though adapted to local codes, it has been applied internationally, and encompasses the whole building life cycle, including: design, operation, and refurbishment. BREEAM evaluates the environmental performance of buildings across eight factors: land use, transport, energy, water, materials, waste, pollution, and management. With the first-mover advantage into the marketplace, BREEAM accounts for $80 \%$ of the sustainable building certifications in Europe, which totalled some 560,000 buildings in 2017. By 2017, BREEAM had expanded to 75 countries [44]. Its market penetration success is attributed to the support it provides building professionals by way of certification manuals, and the attractive rating system it offers: fair, good, very good, and excellent-with three, if not all four, of the awards reading as positive [45]. At its core, BREEAM measures energy usage, with certification available to buildings achieving as little as a $6 \%$ energy cost reduction over non-certified buildings [46].

LEED stands for Leadership in Energy and Environmental Design, and was developed in the United States (US). Though introduced well after BREEAM, in 1998, it is now perhaps the mostly widely adopted rating system. It operates in over 160 countries, with over 15 billion square feet of building space certified. LEED's assessment categories are: site, water, energy, materials, resources, and indoor environmental quality [47]. CASBEE, on the other hand, is largely limited to its country of origin, Japan-though a worldwide version was piloted in 2015, and is expected to be offered globally in the near future. CASBEE stands for Comprehensive Assessment System for Built Environment Efficiency; it was developed by a consortium of government, industry and academia. While presently limited in market distribution, it does evaluate a much broader combination of sustainability factors, extending its scope of assessment from buildings to embrace city and urban contexts in which the deeper issues of sustainability are grounded. In light of this, CASBEE takes on a different approach to assessment. Rather than summing credits across a range of categories, as do most systems, it evaluates the trade-off between the positive improvements achieved with regard to a building's internal "Built Environment Quality" against the negative impacts that result on the building's surrounding context in the form of the "Built Environment Load". The scheme recognises that positive benefits achieved within a building may come at the expense of its surroundings, and that these externalities are overlooked in other rating schemes [48].

Green Star was developed in Australia in 2003, drawing on the BREEAM model, while adapting it to Australian conditions. Green Star NZ (New Zealand) is a further adaptation, extrapolating the Australian Green Star to New Zealand requirements; it was launched in 2007. The Building 
Sustainability Index (BASIX), Evaluation Manual for Green Buildings (EMGB), and National Australian Building Environmental Rating System (NABERS) are further rating permutations that have been developed by government, adding or subtracting various factors, while adjusting the weightings given to each. Most other rating systems are privately developed, and again tailored to different markets and different client needs. A summary of some of the better-known rating tools are provided in Table 1.

In fact, in just about every locality, you will find a plethora of additional software programs, excel spreadsheets, and other instruments offered by maverick operators that can be downloaded and utilised to generate a tailored sustainability rating. For example, the Cooperative Research Centres Program in Australia hosts a 'Low-Carbon Living' website on which 13 tools are listed, along with the developers' contact information. These tools promise all sorts of measures: energy cost predictions from weather data, carbon value engineering, degree of comfort loss in raising house energy efficiency, embodied carbon flows in supply chains, predicted energy load changes as a product of design variation, sustainability gains from co-opting community groups in design processes, behavioural change programme effectiveness, and, psychological readiness to engage in sustainability [49].

Table 1. Summary of major built environment sustainability performance assessment instruments (compiled by authors-Refer Ding [45], Jackson [50]). UN: United Nations; USA: United States of America.

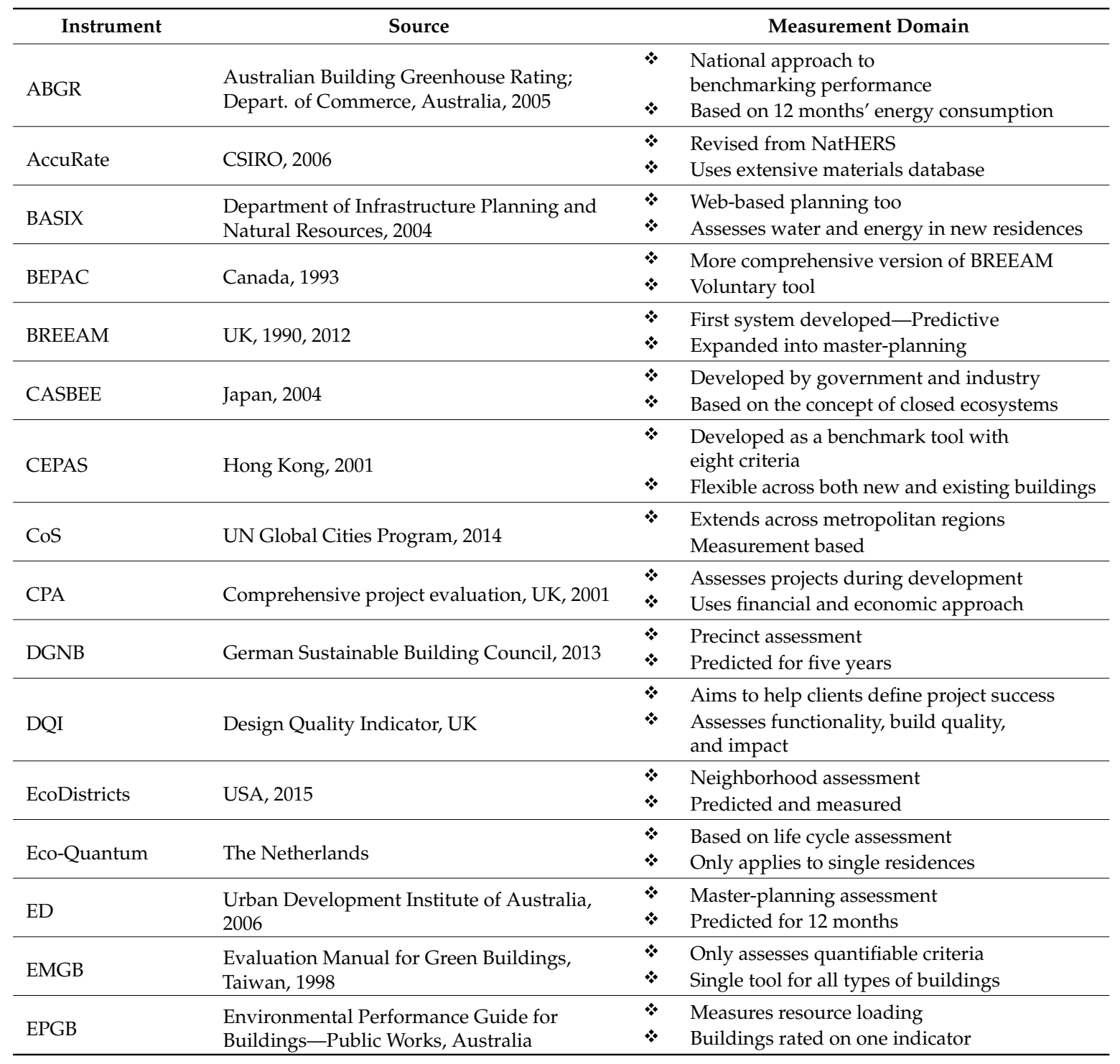


Table 1. Cont.

\begin{tabular}{|c|c|c|}
\hline Instrument & Source & Measurement Domain \\
\hline GBTool & $\begin{array}{l}\text { Green Building Challenge, Worldwide-over } \\
20 \text { countries, } 1995\end{array}$ & $\begin{array}{l}* \quad \text { Comprehensive framework } \\
* \quad \text { Over } 90 \text { performance criteria }\end{array}$ \\
\hline GHEM & Green home evaluation, China, 2001 & $\begin{array}{ll}* & \text { Measures environmental } \\
& \text { performance standards } \\
* \quad \text { No weightings of assessment criteria }\end{array}$ \\
\hline Green Mark & $\begin{array}{l}\text { Building and Construction Authority of } \\
\text { Singapore }\end{array}$ & $\begin{array}{l}* \quad \text { Master-planning assessment } \\
* \quad \text { Predicted }\end{array}$ \\
\hline Green Star & Green Building Council, Australia, 2012 & $\begin{array}{l}* \quad \text { Measures commercial buildings only } \\
\text { * Ratings from } 0 \text { to } 6 \text { stars }\end{array}$ \\
\hline HKBEAM & $\begin{array}{l}\text { Hong Kong building environmental } \\
\text { assessment method, HK, } 1996\end{array}$ & $\begin{array}{ll}* & \text { Based on BREEAM } \\
& \text { Separate systems for new and } \\
\text { existing buildings }\end{array}$ \\
\hline LCC & $\begin{array}{l}\text { Living Community Challenge-International } \\
\text { Future Institute, USA, } 2014\end{array}$ & $\begin{array}{ll}* & \text { District assessment } \\
* & \text { Independent third-party certification }\end{array}$ \\
\hline LEED & $\begin{array}{l}\text { Leadership in Energy and Environmental } \\
\text { Design, USA, } 2000\end{array}$ & $\begin{array}{l}* \quad \text { Developed to create an industry standard } \\
* \quad \text { Voluntary self-assessment tool }\end{array}$ \\
\hline NABERS & $\begin{array}{l}\text { Department of Environment and Heritage, } \\
\text { Australia, } 2001\end{array}$ & $\begin{array}{ll}* & \text { For existing commercial and } \\
& \text { residential buildings } \\
* & \text { Voluntary self-assessment tool } \\
\end{array}$ \\
\hline NatHERS & CSIRO, Australia & $\begin{array}{l}* \quad \text { Computer-based house energy rating system } \\
* \quad \text { Considers design, insulation, and climate }\end{array}$ \\
\hline OPC & $\begin{array}{l}\text { One Planet Communities_-Bioregional } \\
\text { Development Group, UK, } 2004\end{array}$ & $\begin{array}{ll}* & \text { Neighborhood design and as built } \\
* & \text { Predicted and measured verification }\end{array}$ \\
\hline SBAT & $\begin{array}{l}\text { Sustainable building assessment tool, South } \\
\text { Africa }\end{array}$ & $\begin{array}{l}* \quad \text { Based on building life cycle } \\
* \quad \text { Considers social and economic issues }\end{array}$ \\
\hline SPeAR & $\begin{array}{l}\text { Sustainable project appraisal routine-Ove } \\
\text { Arup }\end{array}$ & $\begin{array}{l}* \quad \text { Used for rapid review of project sustainability } \\
* \quad \text { Graphical format to present sustainable design }\end{array}$ \\
\hline
\end{tabular}

\section{Academic Contribution to Sustainability Tool Development}

Mirroring this expansion of rating tools has been a burst of academic research on the subject. A recent review study by Li et al. of papers published between 2004 and 2016 identified a total of 57 peer-reviewed articles that made direct comparisons between building assessment methods. Coincidently, these 57 papers examined and compared exactly 57 assessment methods [51]; 74\% of the papers made general comparisons between assessment methods, while $70 \%$ made category comparisons, 51\% made criterion comparisons, and 33\% made indicator comparisons between assessment methods [51].

The agenda behind much of the academic research is to foster further variation and embellishment to the list of sustainability factors. The hope is to advance what we already have with ever more sophisticated, all-encompassing, and nuanced schemes. That is, not only is there strong competition among the many sustainability tools on offer, there is also strong pressure to develop even more. Building on the core notion of sustainability as the equilibrium of economic, environmental, and social objectives, Silvius et al., writing in the specific context of project management, parses these into 36 sub-categories, citing disparate concepts such as freedom of association, organisational learning, and diversity as recommended project sustainability checklist items [52]. Swarup et al. identify 40 metrics for ascertaining building performance, including project team selection process, onerous contract clauses, and deviation in actual project cost over projected project cost [53]. At times, it would seem that these studies simply attempt to capture everything that can be thought of; measures and weighting are necessarily subjective. Moreover, the very practice of ballooning the range sustainability factors blurs the boundaries between sustainability performance with that of the building project itself: they become one and the same. 
Complementing this interest in the fine-grained performance measurement of building projects is a parallel effort to expand the scope of sustainability beyond the singular point at which the building comes into operation. In assessing the sustainability of projects, Marjaba and Chidiac take the core criteria of economic, environmental, and social objectives, and then lay them out over the three phases of a project's life cycle: manufacturing and construction, occupancy and use, and demolition and reuse. Sustainability performance thus becomes the cumulative performance across many decades of the building's existence. In this regard, site quality, process quality, and technical quality are added dimensions to traditional sustainability metrics [54]. Sustainability measurement has spread horizontally across the value chain, from raw material extraction, through material fabrication, component manufacturing, transportation, construction, use, maintenance, refurbishment, decommissioning, demolition, and recycling. Characteristically, academics have filled these stages with a plethora of sustainability measures; Shen et al. recommended some 112 checklist items covering a project's life cycle [55]. It has also spread vertically across construction sectors, from residential, commercial, industrial, manufacturing, petroleum, energy, transport, and into various other infrastructure domains; each with their own finely tailored sustainability criteria [56].

If that were not enough, even within these many, increasingly narrow criteria, further refinements and qualifications are recommended. In considering just the matter of housing affordability within the broader context of sustainability, Pullen et al. proposed an assessment framework with some 29 considerations [57]. While adding more and more layers of assessment, with greater and greater numbers of performance criteria, may appear cumbersome, if not simply disingenuous, the approach does recognise that a "systems thinking method", in which components must be considered in terms of their relationships with all others, is fundamental to making meaningful headway. The problem of course remains as to what to do with this ever-expanding list of criteria, once identified. What is the strength of the relationship between factors, and how can these be addressed as a system, rather than as merely a list?

\section{The Limits of Sustainability Rating Tools}

Building environmental assessment methods are considered one of the most potent and effective means to improve the performance of buildings [51]. This quotation sums up the prevailing architectural narrative on sustainability. Liu et al. went on to add: Defining new assessment items is important ... due to the fact that existing assessment tools may not always be able to objectively or accurately reflect a building's sustainability ... In other words, the recommended solution to the problem with rating tools, is more rating tools.

Indeed, it has become the fashion to rate rating tools. In a comparative study conducted by Doan et al., BREEAM was deemed the strongest rating system, and Green Star NZ the weakest [34], even though Green Star NZ was derived from BREEAM, but adapted to particular local requirements, as shown in Figure 5. Whole sustainability regimes have come under the spotlight. Bond et al. compare the sustainability assessment practices of England, Western Australia, Canada, and South Africa, pointing out again that sustainability is a game of trade-offs, and that ultimately everybody has different priorities as to what they are willing to give up in order to gain something else. Underlying this narrative is not so much that sustainability is subjective, and that each should be left to his own in determining where the right balance might be between economic, environmental, and social objectives, but rather that sustainability has a deeper, political agenda to shape public opinion on where that subjective balance should lie. Competing interests lobby to introduce their aspirations into the ratings game; once included, everybody else becomes compelled to serve this agenda, conforming to ideals that may not be their own, but doing so in order to gain the sustainability star ratings they need.

Resistance to the sustainability movement has not gone unnoticed, but those that are slow to take it up are typically cast as complacent, if not characterised in condescending terms. The study by Swarup et al. comes to the rather obvious conclusion that better sustainability outcomes are achieved when all of the stakeholders are committed: owner, construction contractor, and project team - the earlier their involvement, the better [53]. However, engagement is the product of incentive. Investing 
in green buildings is costly, both in terms of additional consultants and the construction itself [58]. These green costs can inflate project costs by as much as $25 \%$ [59]. Compounding this disincentive are the additional challenges of increased technical difficulty, lengthy approval processes, more complex contractual arrangements, higher project delivery risk, and longer duration to completion.

However, the problem runs deeper. If a sustainability rating system is to work, it must be evidence-based [60]. Yet, despite broad assumptions that the metrics used stand up, there is no consistent environmental data anywhere on the market [61]. In the words of Marjaba and Chidiac, Certification systems, such as LEED, BREEAM and DGNB are found to be useful and successful at meeting their purpose, however they fail to address all of sustainability's requirements. Moreover, these certification systems have yet to produce metrics that are repeatable, reproducible, and a true reflection of the building performance [54]. An emerging body of research is finding that participants in environmental rating performance schemes sometimes show no better performance than non-participants [9].

What'a more, it could be worse than that. Despite the intuitive appeal of solar panels as a vehicle for reducing dependency on carbon-based energy and green-house gas emissions, it turns out that the embodied energy in manufacturing solar panels, along with the contaminants released into the environment at the time of their disposal, may outweigh the actual environmental credits gained from their use [62]. This counterproductive side effect of going green extends to the building project itself. Current Australian building energy efficiency regulations do not consider embodied energy. Yet, a study by Crawford et al. showed that while increasing the thermal energy rating of a building envelope can improve the energy performance of a building, that gain may in fact be offset by the increased embodied energy required to make insulating materials and windows more energy efficient. Specifically, Crawford determined that with an embodied energy of +572 gigajoules (GJs) for rated Melbourne houses, the life cycle energy benefit was negligible, while for rated Brisbane houses, with an embodied energy of +422 GJs, the life cycle energy demands actually increased [63]. A recent study conducted by the University of South Australia used the AccuRate energy simulation software program to compare the energy performance of six and eight star-rated homes in Sydney and Adelaide with so-called traditional energy inefficient buildings. While NatHERS endorsed the star-rated homes, their over-reliance on air-conditioning in fact made them far less heat stress resistant than unrated traditionally designed houses [8].

In sum, rating tools differ in what they measure; the range and their weightings are largely subjective, reflecting political aspirations more than scientific accuracy. While systems that require energy monitoring-such as Singapore's Green Mark—have emerged, for the most part, rating tools depend heavily of project documentation in making those measurements, leaving imputed ratings effectively unverified in practice. They tend to be market-oriented, relying on voluntary compliance, with users doing so more to win public relations advances than for anything else. Finally, since most rating systems have not been independently scrutinised, they may not be delivering the environmental benefits they claim [64].

\section{Discussion}

Pre-industrial cities were, for the most part, relatively small islands of human habitation in a sea of natural landscape. Almost all had walls. These provided a defensive barrier, but also demarcated the limits of the city. Within this circumscribed domain, all of its services could be accessed on foot [25]. This has changed entirely. Megacities are becoming the new normal, with dozens of cities carrying populations in excess of 10 million springing up all around the world [65]. Australia, the least populated continent (excluding Antarctica), is $97 \%$ urban, with close to half of all Australians living in or around its two key cities of Melbourne and Sydney, as shown in Figure 6.

The point has been made that this remarkable development arose out of the industrial revolution, with the accompanying urban vision springing from Modernist concepts of progress that themselves were spawned from architectural manifestos such as the "industrial city". However, there is more to be said. In rejecting the past, and past value systems, Modernism as a philosophy sowed the seeds of 
its own destruction. Once the past was overturned, Modernism had no further foundation on which to establish an enduring value system. Consider the Modernist composers of the early twentieth century-Arnold Schönberg, Alban Berg, Anton Webern, and others. They rejected the past traditions of setting music to a key, or composing with a tonal center. Music was instead, atonal, without a recognisable key-indeed composed to be unidentifiable as sitting in any traditional genre. Their compositions were an intellectual rejection of the past. In 1952, John Cage performed a musical piece entitled $4^{\prime} 33^{\prime \prime}$. In the performance, Cage sat in front of a grand piano, and played not a single note. He is quoted as saying: I have nothing to say, and I am saying it [66]. The same can be said for Modernist painters, such as Mark Rothko (blocks of monochromatic paint on canvas) or Jackson Pollock (erratic brush-drippings on canvas). Their works are much lauded, and sell for millions, but the net effect is that they have left art at a dead end. The elephant in the room with regard to all of the traditional arts taken over by Modernism is that, except for the few lingering elite, such art has gravitated to nihilism, and has ceased to be of relevance to mainstream society.

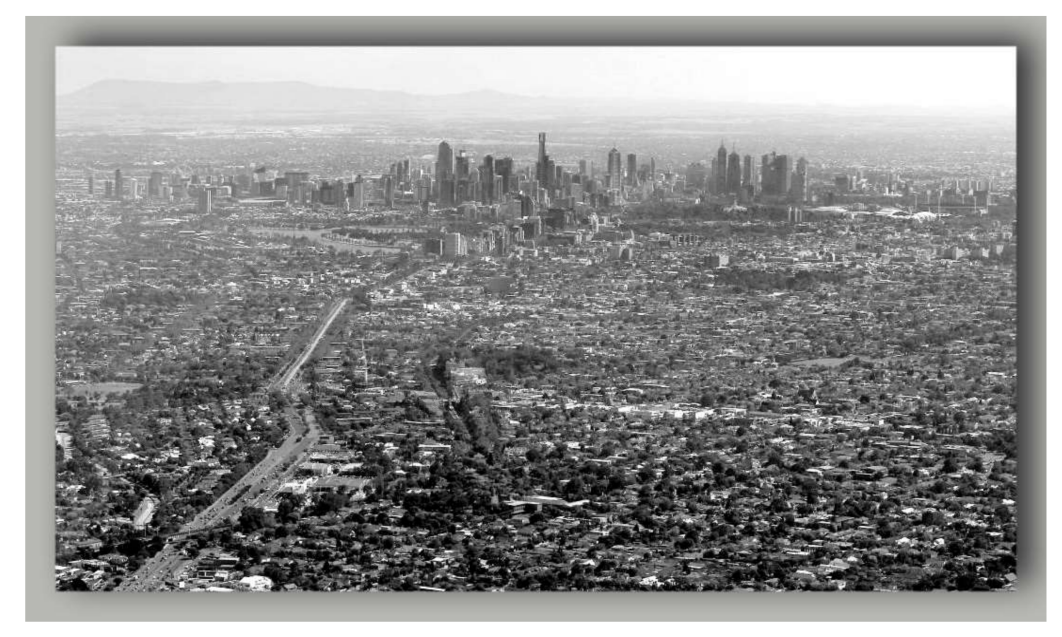

Figure 6. Herald Sun newspaper headline: “Melbourne will need another 720,000 homes by 2031" [67].

The same is true of architecture. Where it once spoke to whole communities, now it is largely limited to the patronage of elite clientele looking to build brand awareness through awards, photo displays, news headlines, or simple notoriety. Good architecture produces a dramatic statement, but often the statement made is empty and narcissistic. Where once students attended architecture schools to be mentored in particular ideals and traditions, now, schools attempt to provide the accreditation that students are looking for in as value-neutral an environment as possible.

Nature abhors a vacuum, and into the vacuum has fallen the cause of sustainability. Sustainability is the new cause célèbre in architecture. It is in this light and against this historic background that the sustainability movement is best understood. As such, sustainability in the built environment is less about how the many variables that comprise a green rating tool are measured, than about what those variables should be. Sustainability is less the science of measurement, and more the philosophy of what matters. Stepping into this space are new evolving iterations of the ratings paradigm. The 'Well Building Standard' is a not-for-profit initiative attempting to explore the effects of buildings on human well-being. Through sustainability, architecture has found a road out of its commercial marketing role and back into the fray of debate about the kind of utopia we want to build for ourselves. Sustainability is a catch all term. It is all things to all people. It is the ground into which new seeds of architectural debate are being sown. The debate is far from settled, but through sustainability, architecture is again venturing towards something meaningful to say and do. 


\section{Conclusions}

Sustainability is a narrative; it is about telling stories. Government, architects, academics, consultants, builders, and the community, each in their many ways, are telling us where they see the right balance between the environment, the economy, and social equity. For mainstream sustainability pundits, the focus has been on environmental issues: improved energy efficiency, better water management, responsible waste treatment, and the like. "Green" proponents hold that resources are finite, and that they are being consumed at an ever-increasing rate. This is where the green rating schemes have their origin. An examination of the best-known rating tools-BREEAM, LEED, Green Star, etc.-reveal their purpose; our "carbon footprint" must be reduced.

A criticism arising is that the most these tools can hope to achieve is to slow the inevitable. As long as populations grow, as long as we take up more land to build, and as long as we consume beyond the capacity for the planet to regenerate, environmental degradation can only be slowed, but never reversed. In this doomsday view, the call is made to increase the range of controls, raise the sustainability bar, and be ever more stringent in demanding compliance. This, again, is the view among those that endorse the mainstream sustainability narrative.

However, there are dissenting views. For one, sustainability is meant to be a balance between the environment and economic growth—not merely a struggle to supplant economic development with environmental idealism. This position has credibility, and is not limited only to the so-called fringe "global warming deniers". In 1798, the mathematician Robert Malthus famously predicted that the increasing population, combined with increasing consumption, would inevitably lead to a collapse of civilisation. Populations grow geometrically, he argued, while food production could only grow arithmetically. There was a time, not far off he said, when there simply would not be enough food to feed everybody [68]. Two things should be noted here. Firstly, this did not happen (as an aside-all famines in history were man-made), yet secondly, the premise to his argument continues to drive Green logic.

Malthus's mistake was to presume that resources are finite; they are not. Technological advances outstrip even population growth, putting us in reach of more and more resources that previously were inaccessible. In ancient times, almost everybody was a farmer-the year-round labor of an individual fed little more than one person. Now, in the US, only $2 \%$ of the population are farmers, and the US is a net exporter of food. In 1940, an acre of land yielded 30 bushels of corn; in 2016, the same acre yielded 170 bushels. Yields continue to increase at the rate of 1.9 bushels, per acre, per year [69]. The variable at play is technology.

Currently, we see the beginnings of a trend away from fossil-fuel powered cars to electric cars. Possibly, within a generation, these will be driverless. However, it should be noted that this is not because oil is running out. In a now oft-quoted statement to the New York Times Magazine, Saudi Arabia's oil minister Sheik Ahmed Zaki Yamani said, The Stone Age didn't end for lack of stone, and the oil age will end long before the world runs out of oil [70]. We are in fact finding oil faster than we are using it. In the last 30 years, proven extractable reserves have grown from 680 billion barrels by some 1000 billion barrels [71], as shown in Figure 7. The shift away from oil—such as it is—is not an expedient, it is value-driven.

Then, there is the third side of the triangle: equity. Sustainability is not just about the environment or economy; it is about fairness. Housing should be affordable, amenities such as proximity to schools, parks, and transport must be considered, and in the workplace, health, well-being and the quality of the work environment must be maintained. These dimensions, too, are finding their way into the rating tools framework. Extreme positions on equity are held. The feminist Hayden, writing on the ideal of a non-sexist city, posits ... the private suburban house was the stage set for the effective sexual division of labor. It was the commodity par excellence, a spur for male paid labor and a container for female unpaid labor [72]. For her, the very idea of the suburban house is unsustainable. Other positions are more normative; calling for fair working conditions, fair-trade practices, and a fair distribution of outcomes. 


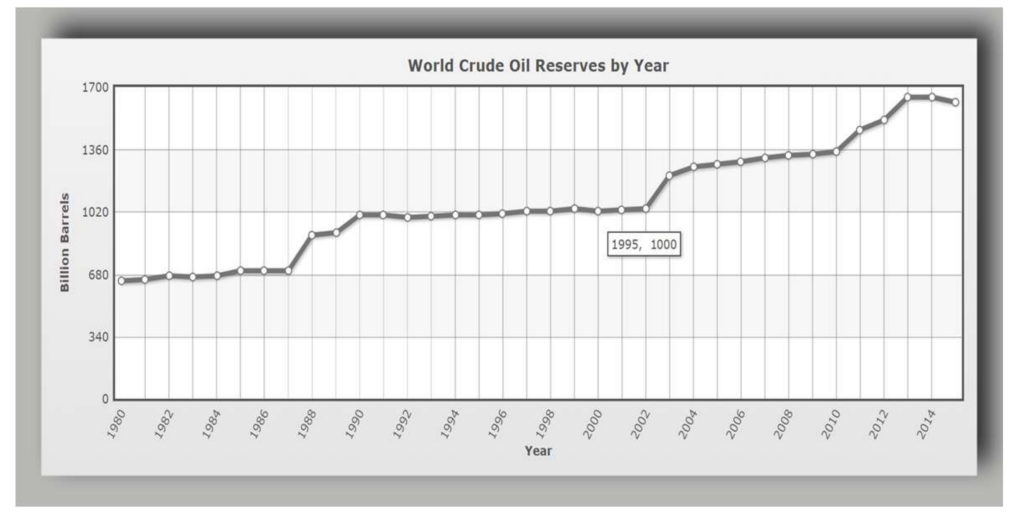

Figure 7. World retrievable crude oil reserves increasing year-on-year, despite consumption rates [71].

In summary, the sustainability project brings together debates about what is economically viable, what is environmentally sound, and what is fair to all. Where that balance ought to be is what is really behind the rise of rating tools. These are physical artifacts of that debate. To some, rating tools cannot be relied on to measure all that is important to sustainability. Returning to Bill McKibben, the world's first recognised environmentalist, we would do well to consider his injunction: Winning slowly is the same as losing [73]. Others go further, suggesting that the sustainability project has merely become a meal ticket to its new army of consultants and rating tool purveyors, or a convenient new forum by which lobby groups promote narrow self-interests. However, it is also fair to say that sustainability has provided a platform by which architects can explore their passion for bequeathing us all a better built tomorrow.

Acknowledgments: This paper provides a background to the successful Integral Design Futures (IDF) funding scheme's 2017 program: Charting Pre-Design Sustainability Indicators (School of Architecture and Built Environment, Deakin University).

Conflicts of Interest: The authors declare no conflict of interest.

\section{References}

1. Zavadskas, E.K.; Antucheviciene, J.; Vilutiene, T.; Adeli, H. Sustainable decision-making in civil engineering, construction and building technology. Sustainability 2017, 10, 14. [CrossRef]

2. Bonenberg, W.; Kapliński, O. The architect and the paradigms of sustainable development: A review of dilemmas. Sustainability 2018, 10, 100. [CrossRef]

3. Čereška, A.; Zavadskas, E.K.; Cavallaro, F.; Podvezko, V.; Tetsman, I.; Grinbergienè, I. Sustainable assessment of aerosol pollution decrease applying multiple attribute decision-making methods. Sustainability 2016, 8 , 586. [CrossRef]

4. Hosseini, M.R.; Banihashemi, S.; Rameezdeen, R.; Golizadeh, H.; Arashpour, M.; Ma, L. Sustainability by information and communication technology: A paradigm shift for construction projects in iran. J. Clean. Prod. 2017, 168, 1-13. [CrossRef]

5. Foong, D.; Mitchell, P.; Wagstaff, N.; Duncan, E.; McManus, P. Transitioning to a more sustainable residential built environment in sydney? Geogr. Environ. 2017, 4. [CrossRef]

6. Reed, R.; Wilkinson, S.; Bilos, A.; Schulte, K.-W. A Comparison of International Sustainable Building Tools-An Update. In Proceedings of the 17th Annual Pacific Rim Real Estate Society Conference, Gold Coast, Australia, 16-19 January 2011; pp. 16-19.

7. Mattoni, B.; Guattari, C.; Evangelisti, L.; Bisegna, F.; Gori, P.; Asdrubali, F. Critical review and methodological approach to evaluate the differences among international green building rating tools. Renew. Sustain. Energy Rev. 2018, 82, 950-960. [CrossRef]

8. Hatvani-Kovacs, G.; Belusko, M.; Pockett, J.; Boland, J. Heat stress-resistant building design in the australian context. Energy Build. 2018, 158, 290-299. [CrossRef] 
9. van der Heijden, J. On the potential of voluntary environmental programmes for the built environment: A critical analysis of leed. J. Hous. Built Environ. 2015, 30, 553-567. [CrossRef]

10. Van der Heijden, J. The new governance for low-carbon buildings: Mapping, exploring, interrogating. Build. Res. Inf. 2016, 44, 575-584. [CrossRef]

11. Zavadskas, E.K.; Cavallaro, F.; Podvezko, V.; Ubarte, I.; Kaklauskas, A. Mcdm assessment of a healthy and safe built environment according to sustainable development principles: A practical neighborhood approach in vilnius. Sustainability 2017, 9, 702. [CrossRef]

12. Zavadskas, E.K.; Bausys, R.; Kaklauskas, A.; Ubarte, I.; Kuzminske, A.; Gudiene, N. Sustainable market valuation of buildings by the single-valued neutrosophic mamva method. Appl. Soft Comput. 2017, 57, 74-87. [CrossRef]

13. Meadows, D. Limits of Growth; Club of Rome, Chelsea Green Publishing: New York, NY, USA, 1972.

14. McKibben, W. The End of Nature; Penguin, Random House: New York, NY, USA, 1989.

15. McKibben, W. Buzzless buzzwords. New York Times, 10 April 1996.

16. Mazmanian, D.; Kraft, M. Towards Sustainable Communities: Transition and Transformation in Environmental Policy; MIT Press: Cambridge, MA, USA, 2009.

17. WCED World Commission on Environment and Development. Our Common Future; Oxford University Press: Oxford, UK, 1987.

18. Aarseth, W.; Ahola, T.; Aaltonen, K.; Økland, A.; Andersen, B. Project sustainability strategies: A systematic literature review. Int. J. Proj. Manag. 2017, 35, 1071-1083. [CrossRef]

19. Zuofa, T.; Ochieng, E. Sustainability in construction project delivery: A study of experienced project managers in nigeria. Proj. Manag. J. 2016, 47, 44-55. [CrossRef]

20. Bartlett, A. Reflections on sustainability, population growth and the environment-Revisited. Renew. Resour. J. 1998, 15, 6-23.

21. Dryzek, J. The Politics of the Earth: Environmental Discourses, 2nd ed.; Oxford University Press: Oxford, UK, 2005.

22. Caradonna, J. Sustainability: A History; Oxford University Press: New York, NY, USA, 2016.

23. Portney, K. Sustainability; MIT Press: Cambridge, MA, USA, 2015.

24. Hobbes, T. Leviathan; Penguin Books: Baltimore, MD, USA, 1968.

25. Ponting, C. A Green History of the World; Penguin: London, UK, 2011.

26. Craven, J. Architecture Timeline-Historic Periods and Styles of the West. Available online: https: / / www. thoughtco.com/architecture-timeline-historic-periods-styles-175996 (accessed on 28 January 2018).

27. Collins, P. Changing Ideals in Modern Architecture; Faber and Faber: London, UK, 2006.

28. Stinson, L. Remembering the Legend behind form Follows Function. Available online: https:/ / www.wired. com/2015/09/man-coined-form-follows-function-born-today/ (accessed on 27 March 2018).

29. Pevsner, N. The Sources of Modern Architecture and Design; Cambridge University Press: Cambridge, UK, 2010.

30. World Population Balance. The Global Population Situation-An Overview. Available online: http://www. worldpopulationbalance.org/global_population (accessed on 27 March 2018).

31. Garnier, T.; Pawlowski, C. Une Cite Industrielle; Il Balcone: Paris, France, 1967.

32. Wiebenson, D. Utopian aspects of tony garnier's cité industrielle. J. Soc. Arch. Hist. 1960, 19, 16-24. [CrossRef]

33. Banihashemi, S.; Tabadkani, A.; Hosseini, M.R. Integration of parametric design into modular coordination: A construction waste reduction workflow. Autom. Constr. 2018, 88, 1-12. [CrossRef]

34. Doan, D.T.; Ghaffarianhosseini, A.; Naismith, N.; Zhang, T.; Ghaffarianhosseini, A. A critical compariosn of green building rating systems. Build. Environ. 2017, 123, 243-260. [CrossRef]

35. Dixit, M.K.; Culp, C.H.; Fernandez-Solís, J.L. System boundary for embodied energy in buildings: A conceptual model for definition. Sustain. Energy Rev. 2013, 21, 153-164. [CrossRef]

36. Wong, J.K.W.; Zhou, J. Enhancing environmental sustainability over building life cycles through green bim. Autom. Constr. 2015, 57, 156-165. [CrossRef]

37. Udawatta, N.; Zuo, J.; Chiveralls, K.; Zillante, G. Attitudinal and behavioural approaches to improving waste management on construction projects in australia. Int. J. Constr. Manag. 2015, 15, 137-147.

38. Nikmehr, B.; Hosseini, M.R.; Rameezdeen, R.; Chileshe, N.; Ghoddousi, P.; Arashpour, M. An integrated model for factors affecting construction and demolition waste management in Iran. Eng. Constr. Archit. Manag. 2017, 24, 1246-1268. [CrossRef] 
39. Cooper, I. Transgressing discipline boundaries. Build. Res. Inf. 2002, 27, 321-331. [CrossRef]

40. Mardani, A.; Jusoh, A.; Zavadskas, E.K.; Cavallaro, F.; Khalifah, Z. Sustainable and renewable energy: An overview of the application of multiple criteria decision making techniques and approaches. Sustainability 2015, 7, 13947-13984. [CrossRef]

41. Wilkinson, S. Report for Royal Institution of Chartered Surveyors; Royal Institution: London, UK, 2014.

42. Vierra, S. Green Building Standards and Certification Systems; National Institute of Building Sciences: Washington, DC, USA, 2011.

43. Mao, X.; Lu, H.; Li, Q. A comparison study of mainstream sustainable/green building rating tools in the world. In Proceedings of the International Conference on Management and Service Science, Wuhan, China, 20-22 September 2009; pp. 1-5.

44. BREEAM. Breeam Homepage. Available online: http:/ /www.breeam.com/ (accessed on 12 February 2018).

45. Ding, G. Sustainable construction-The role of environmental assessment tools. J. Environ. Manag. 2008, 86, 451-464. [CrossRef] [PubMed]

46. Vimpari, J.; Junnila, S. Value influencing mechanism of green certificates in the discounted cash flow valuation. Int. J. Strateg. Prop. Manag. 2014, 18, 238-252. [CrossRef]

47. LEED. Leed Homepage. Available online: https://new.usgbc.org/leed (accessed on 12 February 2018).

48. CASBEE. Casbee Homepage. Available online: http://www.ibec.or.jp/CASBEE/english/ (accessed on 12 February 2018).

49. Low Carbon Living. Crclcl Tools Catalogue. Available online: http://www.lowcarbonlivingcrc.com.au/ resources/crc-publications/fact-sheet/crclcl-tools-catalogue (accessed on 12 February 2018).

50. Jackson, S. A summary of urban assessment tools for application in australia. In Environment Design Guide; Australian Institute of Architects: Melbourne, Australia, 2016.

51. Li, Y.; Chen, X.; Wang, X.; Xu, Y.; Chen, P. A review of studies on green building assessment methods by comparative analysis. Energy Build. 2017, 146, 152-159. [CrossRef]

52. Silvius, G.; Schipper, R.; Nedeski, S. Consideration of sustainability in projects and project management: An empirical study. In Sustainability Integration for Effective Project Management; IGI Global: Hershey, PA, USA, 2013.

53. Swarup, L.; Korkmaz, S.; Riley, D. Project delivery metrics for sustainable, high-performance buildings. J. Constr. Eng. Manag. 2011, 137, 1043-1051. [CrossRef]

54. Marjaba, G.E.; Chidiac, S.E. Sustainability and resiliency metrics for buildings-Critical review. Build. Environ. 2016, 101, 116-125. [CrossRef]

55. Shen, L.Y.; Hao, J.L.; Tam, V.; Yao, H. A checklist for assessing sustainability performance of construction projects. J. Civ. Eng. Manag. 2010, 13, 273-281.

56. Ortiz, O.; Castells, F.; Sonnemann, G. Sustainability in the construction industry: A review of recent developments based on lca. Constr. Build. Mater. 2009, 23, 28-39. [CrossRef]

57. Pullen, S.; Arman, M.; Zillante, G.; Zo, J.; Chileshe, N.; Wilson, L. Developing an assessment framework for affordable and sustainable housing. Aust. J. Constr. Econ. Build. 2010, 10, 48-64.

58. Metibogun, L.; Baird, G. Integrating green building index consultancy with residential design. In Fifty Years Later: Revisiting the Role of Architectural Science in Design and Practice: 50th International Conference of the Architectural Science Association; Zuo, J., Daniel, L., Soebarto, V., Eds.; The Architectural Science Association: Adelaide, Australia, 2016.

59. Hwang, B.-G.; Ng, W.J. Project management knowledge and skills for green construction: Overcoming challenges. Int. J. Proj. Manag. 2013, 31, 272-284. [CrossRef]

60. Low Carbon Living. Viable Integrated Systems for Zero Carbon Housing; University of South Australia: Adelaide, Australia, 2014.

61. Tam, V.; Zeng, S.X. Sustainable performance indicators for australian residential buildings. J. Leg. Aff. Disput. Resolut. Eng. Constr. 2013, 5, 168-179. [CrossRef]

62. Mulvaney, D. Solar's Green Dilemma: Must Cheaper Photovoltaics Come with a Higher Environmental Price Tag? Available online:. Available online: http:/ / spectrum.ieee.org/solar0914 (accessed on 12 February 2018). 
63. Crawford, R.; Bartak, E.; Stephan, A.; Jensen, C. Does current policy on building energy efficiency reduce a building's life-cycle energy demand? In Proceedings of the 49th International Conference of the Architectural Science Association Living and Learning: Research for a Better Built Environment, Melbourne, Australia, 2-4 December 2015; pp. 332-341.

64. Wong, S.Y.; Susilawanti, C.; Miller, W.; Mardiasmo, D. A comparison of international and australian rating tools for sustainability elements of residential property. In COBRA; RICS: London, UK, 2015.

65. Khanna, P. Connectography-Mapping the Future of Global Civilization; Random House: London, UK, 2016.

66. Jones, J. The Curious Score for John Cage's "Silent” Zen Composition 4'33". Available online: http:/ / www. openculture.com/2013/10/see-the-curious-score-for-john-cages-silent-zen-composition-433.html (accessed on 23 March 2018).

67. Masanauskas, J. Melbourne's Continuing Population Boom Means Another 720,000 Homes Will Be Needed by 2031; Herals Sun: Melbourne, Australia, 2014.

68. Sachs, J. Are Malthus's Predicted 1798 Food Shortages Coming True? Scientific American, September 2008.

69. Nielsen, B. Historical Corn Grain Yields for the U.S. Available online: https:/ / www.agry.purdue.edu/ext/ corn/news/timeless/yieldtrends.html (accessed on 23 March 2018).

70. Maass, P. The breaking point. New York Times Magazine, 21 August 2005.

71. United States Energy Information Administration. World Crude Oil Reserves by Year. Available online: https: / / www.indexmundi.com/energy / ?product=oil\&graph=reserves (accessed on 23 March 2018).

72. Hayden, D. What would a non-sexist city be like? In Urban Communities in the 21st Century —From Industrialization to Sustainability; Hutson, M., Ed.; University of California: Berkeley, CA, USA, 2010; pp. 219-235.

73. McKibben, W. Winning Slowly Is the Same as Losing. Available online: https:/ /www.rollingstone.com/ politics/news/bill-mckibben-winning-slowly-is-the-same-as-losing-w512967 (accessed on 23 March 2018).

(C) 2018 by the authors. Licensee MDPI, Basel, Switzerland. This article is an open access article distributed under the terms and conditions of the Creative Commons Attribution (CC BY) license (http:/ / creativecommons.org/licenses/by/4.0/). 